\title{
Correction to: Comparison of ethanol concentrations in the human brain determined by magnetic resonance spectroscopy and serum ethanol concentrations
}

\author{
Annette Thierauf-Emberger ${ }^{1} \cdot$ Judith Echle $^{1} \cdot$ Michael Dacko $^{2} \cdot$ Thomas Lange $^{2}$ \\ Published online: 16 July 2021 \\ (c) The Author(s) 2021
Correction to: International Journal of Legal Medicine (2020) 134:1713-1718 https://doi.org/10.1007/s00414-020-02325-w

The article "Comparison of ethanol concentrations in the human brain determined by magnetic resonance spectroscopy and serum ethanol concentrations", written by Annette Thierauf-Emberger, Judith Echle, Michael Dacko and Thomas Lange, was originally published Online First without Open Access. After publication in volume 134, issue 5, page 1713-1718 the author decided to opt for Open Choice and to make the article an Open Access publication. Therefore, the copyright of the article has been changed to (C) The Author(s) 2020 and the article is forthwith distributed under the terms of the Creative Commons Attribution 4.0 International License, which permits use, sharing, adaptation, distribution and reproduction in any medium or format, as long as you give appropriate credit to the original author(s) and the source, provide a link to the Creative Commons licence, and indicate if changes were made. The images or other third party material in this article are included in the article's Creative Commons licence, unless indicated otherwise in a credit line to the material. If material is not included in the article's Creative Commons licence and your intended use is not permitted by statutory regulation or exceeds the permitted use, you will need to obtain permission directly from the copyright holder. To view a copy of this licence, visit http://creativecommons.org/licenses/by/4.0.

The original article can be found online at https://doi.org/10.1007/ s00414-020-02325-w.

Annette Thierauf-Emberger

annette.thierauf@uniklinik-freiburg.de

1 Institute of Forensic Medicine, Medical Center - University of Freiburg, Albertstraße 9, 79104 Freiburg, Germany

2 Medical Physics, Department of Radiology, Medical Center - University of Freiburg, Freiburg, Germany
The original article has been corrected.

Open Access This article is licensed under a Creative Commons Attribution 4.0 International License, which permits use, sharing, adaptation, distribution and reproduction in any medium or format, as long as you give appropriate credit to the original author(s) and the source, provide a link to the Creative Commons licence, and indicate if changes were made. The images or other third party material in this article are included in the article's Creative Commons licence, unless indicated otherwise in a credit line to the material. If material is not included in the article's Creative Commons licence and your intended use is not permitted by statutory regulation or exceeds the permitted use, you will need to obtain permission directly from the copyright holder. To view a copy of this licence, visit http://creativecommons.org/licenses/by/4.0/.

Publisher's note Springer Nature remains neutral with regard to jurisdictional claims in published maps and institutional affiliations. 